\title{
Memaksimalkan Peran Google Form dalam Kegiatan Belajar Mengajar di Era Covid-19
}

\author{
Faroman Syarief $1^{*}$, Kurniawan Prambudi Utomo², Muhammad Aziz Winardi \\ Nasution $^{3}$, Fahmi Kamal ${ }^{4}$ \\ ${ }^{1}$ Universitas Bhayangkara Jakarta Raya, Jakarta, Indonesia \\ ${ }^{2}$ Universitas Bina Sarana Informatika, Jakarta, Indonesia \\ ${ }^{3}$ Sekolah Tinggi Ilmu Ekonomi GICI, Jakarta, Indonesia \\ ${ }^{4}$ Sekolah Tinggi Manajemen IMMI, Jakarta, Indonesia \\ *Corresponding Author: kurniawan.kpu@bsi.ac.id
}

\begin{abstract}
Info Artike1 Diterima: 01/02/2022 Direvisi: 13/02/2022 Disetujui: 19/02/2022
Abstract. The purpose of education is to form students to be able to increase the level of intelligence by transferring the knowledge and technology possessed by teachers. The purpose of this research is to provide understanding and knowledge in the computer field, especially the introduction of making questions through google form to educators at Madrasah Ibtidaiyah (MI) Muhajirin, Bekasi As for the problems that the school has during the current covid-19 pandemic, where some face-to-face learning is limited and some are still teaching online, so the lack of knowledge in applying some computer programs is still found and as well as a lack of understanding in making learning applications using the google form. The method used is through direct observation and interviews, so it is deemed necessary to provide training in the form of workshops to educators so that the results of this study are teachers $u$ are able to create an interactive learning through the google form assignment method to become a capital to explore and expand knowledge in the field of technology.
\end{abstract}

Keywords: Apps, Technology, Learning. \begin{abstract}
Abstrak. Tujuan pendidikan yaitu membentuk peserta didik agar mampu meningkatkan tingkat kecerdasan
dengan mentranfer ilmu pengetahuan dan teknologi yang dimiliki para guru, Adapun tujuan penelitian ini untuk memberikan pemahaman dan pengetahuan di bidang computer terutama pengenalan pembuatan soal melalui google form kepada para pendidik di Madrasah Ibtidaiyah (MI) Muhajirin, Bekasi, Adapun permasalahan yang dimiliki oleh sekolah tersebut dimasa pandemic covid-19 yang masih ada saat ini, dimana pembelajaran Sebagian sudah tatap muka terbatas dan Sebagian masih mengajar dalam jaringan (daring), sehingga kurangnya pengetahuan dalam mengaplikasikan beberapa program computer masih ditemukan dan serta kurangnya pemahaman dalam pembuatan aplikasi pembelajaran dengan menggunakan google form, Adapun metode yang dilakukan yaitu melalui pengamatan langsung dan wawancara, sehingga dirasa perlu memberikan pelatihan dalam bentuk workshop kepada tenaga pendidik sehingga hasil penelitian ini adalah para guru mampu membuat suatu pembelajaran yang interaktif melalui metode penugasan google form untuk menjadi modal mendalami dan memperluas pengetahuan bidang teknologi.
\end{abstract}

Kata Kunci: Aplikasi, Teknologi, Pembelajaran

How to Cite: Syarief, F., Utomo, K. P., Nasution, M. A. W., \& Kamal, F. (2022). Memaksimalkan Peran Google Form dalam Kegiatan Belajar Mengajar di Era Covid-19. Prima Abdika: Jurnal Pengabdian Masyarakat, 2(1), 75-82. https://doi.org/10.37478/abdika.v2i1.1675 Nasution, Fahmi Kamal. This work is licensed under a Creative Commons Attribution-ShareAlike 4.0 International License.

\section{Pendahuluan}

Satuan pendidikan adalah bagian penting dalam membangun bangsa Indonesia yang terhormat dan bermartabat dimasa depan dan sebagai ujung tombak kemampuan untuk membentuk insan atau manusia yang berpendidikan seutuhnya sehingga mampu mengelola sumber daya alam menuju pembangunan juga memegang kedaualatan dalam menjalankan perjalanan dimasa yang akan datang dengan kemampuan menempatkan sumber daya manusia paling tepat dan efisien dan humanis, oleh karenanya penting menjadi tugas Bersama dan berbagi peran semua pihak yang berkepentingan dalam mengelola Pendidikan bangsa ini, mulai dari pemerintah baik pusat maupun daerah sebagai penyelenggara negara dan 
bukti kehadiran negara ditengah masyarakat juga pihak swasta sebagai mitra penyelenggara pendidikan baik dasar maupun menengah dan tinggi, selain pemerintah dan pihak swasta, elemen yang tidak kalah penting yaitu guru, guru menajdi pioneer membangun negara sebagai dasar untuk membentuk generasi peserta didik yang tepat dan berbudaya sesuai dengan amanat undang undang dasar, yaitu mencerdaskan kehidupan bernegara.., sesuai dengan yang dikatakan bahwa dengan education is a core effort in the process of developing human resources. With human education consciously will be directed to develop its potential in the form of abilities, skills, attitudes, and personalities by the objectives of national education. Education is a necessity for every developing nation like Indonesia. With education it is hoped that the creation of a strong and strong Indonesian human being in dealing with various social and individual problems yang artinya Pendidikan merupakan usaha yang dijalankan dalam melakukan mengembangkan potensi mulai dari kemampuan, sikap dan kepribadian terhadap peserta didik, Pendidikan dibutuhkan oleh setiap negeri termasuk Indonesia untuk mengelola permasalahan social dan individu (Kurniawan et al., n.d.).

Dengan pendidikan manusia menjadi sadar akan akam pentingnya mengelola persoalan yang terjadi dari sudut pandang Bersama dan kepentingan Bersama dengan menggunakan akal dan kemampuannya seperti kemampuan dibidang manajemen, teknologi sehingga permasalahan yang terjadi dapat diminimalisir sekecil mungkin, pendidikan diharapkan terciptanya manusia Indonesia yang kuat dan tangguh berada dalam menghadapi berbagai sosial dan masalah individu. Seiring dengan perkembangan tenknologi, pendidikan juga dapat berlari cepat dalam memajukan pendidikan bangsa, yang sudah masuk ke dalam pendidikan dasar, telebih dunia, khususnya Indonesia masih dalam era covid-19 yang memaksa pendidikan tidak melulu berada diruang kelas.

Mengingat penyebaran virus ini, sehingga diperlukan pendidikan yang tidak boleh terputus, dan harus tetap berjalan kapanpun dan dimanapun, melalui pendidikan formal maupun pelatihan-pelatihan di segala lapisan masyarakat kewirausahaan menjadi berkembang (Sumarsid \& Winarso, 2020). Pemerintah dalam hal ini dinas pendidikan semakin berupaya untuk mengembangkan model pendidikan dan pelatihan yang berbasis offline dan online, hal ini sesuai dengan pendapat yang mengatakan bahwa digital technology and communication that has penetrated in Indonesia is being felt and increasingly fast, the Government in this case must be able to provide solutions in the form of training for human resources in the future both regarding digital skills training and training, given the civilization of a nation determined by education and human skills in it atau teknologi dan komunikasi digital yang sudah merambah di Indonesia semakin terasa dan semakin pesat. Pemerintah dalam hal ini harus mampu memberikan solusi berupa pelatihanpelatihan bagi sumber daya manusia di masa yang akan datang untuk meningkatkan kualitas sumber daya manusia Indonesia (Enny, 2019)baik mengenai pelatihan maupun pelatihan keterampilan digital mengingat peradaban bangsa suatu bangsa ditentukan oleh pendidikan dan keterampilan manusia di dalamnya (Syarief et al., 2019).

Dua lebih setahun sudah dampak Covid 19 terjadi di seluruh dunia, berdampak pada kualitas layanan, baik pendidikan yang belum maksimal juga ada dugaan dampak motivasi semangat belajar, sehingga perlu dilakukan 
pembelajaran secara daring dan para pendidik harus tetap bekerja Work From Home (WFH) dan Work From Office (WFO) agar Pendidikan dan pengajaran berjalan terus menerus"(Utomo, Supriyanto \& Winardi, 2020). Pendidikan harus tetap berjalan sampai kapanpun karena merupakan amanat konstitusi Undang Undang Dasar 1945. Pendidikan adalah upaya inti dalam proses dalam mengembangkan sumber daya manusia. Dengan pendidikan manusia secara sadar akan diarahkan untuk mengembangkan potensinya berupa kemampuan, keterampilan, sikap, dan kepribadian sesuai dengan tujuan pendidikan nasional. Pendidikan merupakan kebutuhan bagi setiap negara berkembang seperti Indonesia. Dengan pendidikan diharapkan terciptanya manusia Indonesia yang tangguh dan tangguh dalam menghadapi berbagai permasalahan sosial dan individu. Mata pelajaran pendidikan kewarganegaraan menitikberatkan pada pembentukan warga negara yang memahami dan dapat melaksanakan hak dan kewajibannya untuk menjadi warga negara Indonesia yang cerdas, terampil, dan berkarakter sebagaimana diamanatkan oleh Pancasila dan UUD 1945.

Secara normatif (Utomo \& Kamal, 2020), pandemi COVID-19 merupakan krisis kesehatan yang terjadi di seluruh dunia, berbagai sektor terdampak akan adanya pandemi ini termasuk sektor pendidikan. Akibat dampak tersebut kebijakan yang diambil oleh banyak Negara termasuk Indonesia adalah dengan meliburkan seluruh aktivitas pendidikan yang akhirnya membuat pemerintah dan lembaga terkait harus menghadirkan alternatif proses pendidikan bagi peserta didik maupun mahasiswa yang tidak bisa melaksanakan proses pendidikan pada lembaga pendidikan.

Pemerintah juga mengambil peran dalam menangani ketimpangan kegiatan belajar selama pandemi covid-19 ini. Melansir laman resmi Kemendikbud RI, ada 12 platform atau aplikasi yang bisa diakses pelajar untuk belajar di rumah yaitu (1) Rumah belajar; (2) Meja kita; (3) Icando; (4) Indonesiax; (5) Google for education; (6) Kelas pintar; (7) Microsoft office 365; (8) Quipper school (9) Ruang guru; (10) Sekolahmu; (11) Zenius; (12) Cisco webex"(Sourial et al., 2018). Hal ini sesuai dengan kebijakan Menteri Pendidikan dan Kebudayaan Republik Indonesia terkait Pelaksanaan Kebijakan Pendidikan dalam Masa Darurat Penyebaran Corona Virus Disease (COVID-19). Perlu disadari bahwa ketidaksiapan guru dan siswa terhadap pembelajaran daring juga menjadi masalah. Perpindahan sistem belajar konvensional ke sistem daring amat mendadak, tanpa persiapan yang matang. Tetapi semua ini harus tetap dilaksanakan agar proses pembelajaran dapat berjalan lancar dan siswa aktif mengikuti walaupun dalam kondisi pandemi Covid-19 (Suhendri et al., 2021).

Pesantren dan Madrasah sebagai simbol lembaga pendidikan islam di Indonesia. Selain itu madrasah sebagai satuan pendidikan formal yang setara dengan sekolah umum, maka diupayakan agar memiliki tenaga pendidik yang cukup. Maskur (2021) menyatakan bahwa problem-problem yang dihadapi di madrasah adalah administrasi yang belum dibenah dengan baik, team working lemah, kurangnya kelengkapan kearsipan madrasah, kurangnya partisipasi masyarakat terhadap pembangunan pendidikan, kurangnya fasilitas dan kelengkapan belajar di kelas, dan rendahnya kualitas SDM dari masyarakat sekitar madrasah. 
Pembelajaran dimasa pandemi ini semua sekolah diwajibkan untuk belajar secara online. Pembelajaran online adalah pembelajaran yang diselenggarakan melalui jejaring web dimana seorang guru menyediakan materi dalam bentuk rekaman video atau slideshow dengan disertai tugastugas baik dalam bentuk tulisan maupun bergambar, salah satu contohnya adalah Yayasan Madrasah Muhajirin, Bekasi. Saat ini untuk tingkat MI dan MA tidak bisa lama bertahan dikarenakan tidak bersaing dengan sekolah lain, sehingga tidak bisa dilanjutkan dan hanya sampai tingkat MTs saja. Dalam proses belajar-mengajar khususnya dalam pemberian tugas pada setiap mata kuliah yang terkait guru mengalami kendala dalam mengolah menyimpan dan menilai tugas-tugas yang diberikan kepada siswa. Penggunaan google forms dapat memberikan alternatif kepada guru dalam mengorganisasikan penugasan mata kuliah. Keuntungan menggunakan google forms adalah efektif, efisien, interaktif serta meminimalkan penggunaan kertas, hal ini dilalakukan untuk meningkatkan kinerja guru-guru, hal ini sesuai dengan definisi kinerja bahwa kinerja merupakan suatu hasil atau pencapaian atas kerja seseorang dalam sebuah lingkup organisasi.

Hasil kerja yang diperoleh baik secara kualitas maupun kuantitas sesuai tanggung jawab yang telah diberikan sehingga hasil kerja tersebut dapat dievaluasi (Lestiowati et al., 2021). Sementara itu kendala/kelemahan dalam menggunakanya adalah ketika koneksi internet tidak berjalan dengan baik atau terputus (Iqbal, 2018). Permasalahan yang dimiliki oleh Yayasan Madrasah Muhajirin, Bekasi adalah munculnya wabah penyakit Virus Corona (COVID-19) yang belum selesai sehingga memaksa mereka untuk menjaga keselamatan dan kesehatan para tenaga pendidik dan siswa. Sistem pembelajaran saat ini harus dilakukan secara online (Daring), dimana pada proses pembelajarannya masih kurang efektif dan efisien dikarenakan kurangnya pemahaman pengetahuan mereka dalam mengaplikasikan beberapa program yang berada di Smartphone maupun laptop yang mereka miliki. Proses kegiatan belajar saat ini hanya mengandalkan aplikasi chatting (Whatsapp) untuk komunikasi antara pihak sekolah dengan siswa seperti mengirimkan soal latihan, sistem tanya jawab dan mengirimkan mata pelajaran serta kurangnya pemahaman dalam pembuatan aplikasi pembelajaran dengan menggunakan Google Form.

\section{Metode Pelaksanaan}

Dalam pelaksanaan kegiatan Pengabdian Masyarakat ini, pengajar akan memberikan materi pelatihan pembelajaran secara daring tentunya dengan semangat dan motivasi peserta untuk mengikuti kegaitan sampai tuntas, sesuai yang dikatakan bahwa one of the factors to improve employee work is motivation, yang berarti, salah satu factor terpenting dalam bekerja adalah motivasi yang kuat, sehingga kegiatan akan mudah dilaksanakan dan berhasil secara efektif dan efisien (Yusuf et al., 2020), kegiatan belajar mengajar dilaksanakan dengan jaga jarak dan menerapkan protokol kesehatan yang cukup ketat. Selain itu, pengunaan aplikasi zoom turut digunakan untuk melengkapi pelaksanaan pengabdian masyarakat tersebut.

a. Tim pengabdian melakukan survei lokasi pada bulan September 2021 .

b. Persiapan pengabdian masyarakat, waktu, materi dan teknis oleh tim.

c. Konfirmasi dengan ketua Yayasan Madrasah Muhajirin, Bekasi sebagai tempat pelaksanaan pengabdian 
d. Pelaksanaan di ikuti oleh guru-guru Madrasah Muhajirin, Bekasi.

e. Penyampaian materi dengan metode ceramah oleh tim secara online

f. Metode ceramah digunakan untuk memberikan pengetahuan dan pemahaman tentang optimalisasi pembelajaran teknologi daring di masa pandemic Covid 19 melalui google form.

Selanjutnya, dalam kegiatan pengabdian ini peserta diajak berdiskusi untuk mampu mengenal dan termotivasi untuk memanfaatkan dan menggunakan optimalisasi pembelajaran teknologi daring di masa pandemic Covid 19 melalui google form dan memberikan pelatihan dalam bentuk workshop kepada orang tua dan siswa agar memiliki kemampuan membuat suatu presentasi yang menarik dan interaktif. Kemampuan dalam membuat presentasi ini dapat menjadi modal mereka untuk mendalami dan memperluas pengetahuan mereka di bidang teknologi ini.

\section{Hasil dan Pembahasan}

Universitas yang diwakili oleh Dosen dan Mahasiswa, secara bertahap, kembali melakukan program Pengabdian Masyarakat berupa Penerapan Aplikasi Google Form di dalam Pembelajaran pada Yayasan Madrasah Muhajirin, Bekasi dimasa pandemic Covid-19 yang sudah hampir dua tahun. Walaupun pembelajaran tatap muka terbatas (PTMP) sudah mulai dilakukan bertahap, kali ini masih menggunakan daring yang berlangsung pada tanggal 9 Oktober 2021. Kegiatan itu diikuti lebih dari 30 peserta dari Guru-guru MTs Muhajirin, Bekasi dengan antusias, dipandu oleh Tutor pengabdian masyarakat, Universitas, beserta dengan tim dan dikuti juga beberapa mahasiswa, dengan mendampingi dan memberikan pelatihan pengabdian masyarakat, dengan langsung dengan materi Pemanfaatan Media online google form sebagai media pembelajaran dalam Mengisi kegiatan selama Masa Pandemi Covid 19 ini.

Para peserta kegiatan Pengabdian Masyarakat sangat senang dan antusias mengikuti kegiatan walaupun mengikuti dengan media online Zoom meeting. Kegiatan berlangsung sejak pagi sampai sore hari. Tema kegiatan dan pelatihan Penerapan Aplikasi Google Form di dalam Pembelajaran pada Yayasan Madrasah Al Muhajirin merupakan bentuk kepedulian dan tanggung jawab bersama serta simpati terhadap masyarakat di sekitar guru-guru MTS Muhajirin, Bekasi. Selain memang sudah merupakan kewajiban dalam pelaksanaan Tri Dharma Perguruan Tinggi sebagai point pengabdian masyarakat dan tanggung jawab bersama sesama manusia insan pendidikan untuk saling mengisi dan membantu, juga merupakan tanggung jawab kami sebagai dosen dan mahasiswa dalam berperan dalam melaksanaan pengabdian tersebut yang diamanatkan Undang Undang Pendidikan yaitu pengabdian terhadap masyarakat.

Adapun permasalahan dapat diidentifikasi atas dasar analisis situasi, beberapa persoalan atau permasalahan yang ditemukan oleh Tim Pengabdian Masyarakat, diketahui bahwa:

1. Kurangnya pemahaman teknologi informasi dalam pembuatan aplikasi pada Google Form

2. Kurangnya sumber referensi dalam pembelajaran aplikasi pada Google Form 
3. Banyaknya dana yang harus dikeluarkan untuk membayar pengajar yang berpengalaman di bidang ilmu teknologi informasi.

Berdasarkan permasalahan tersebut, tim pelatih dari pengabdian masyarakat mencoba untuk berdiskusi dan menawarkan pemecahan masalah yaitu sebagai berikut:

1. Permasalahan di atas, maka perlu adanya sebuah pelatihan sehingga dapat memahami ilmu (teori) dari Google Form kepada Yayasan Madrasah Muhajirin, Bekasi.

2. Memiliki keterampilan dalam pembuatan soal dengan Google Form khususnya di wilayah Yayasan Madrasah Muhajirin, Bekasi (sebagai peserta)

Para peserta kegiatan Pengabdian Masyarakat sangat senang dan antusias mengikuti kegiatan walaupun mengikuti dengan media online Zoom, kegiatan yang berlangsung sejak pagi sampai sore hari, adapun pengabdian masyarakat dapat dilihat pada gambar dibawah ini:

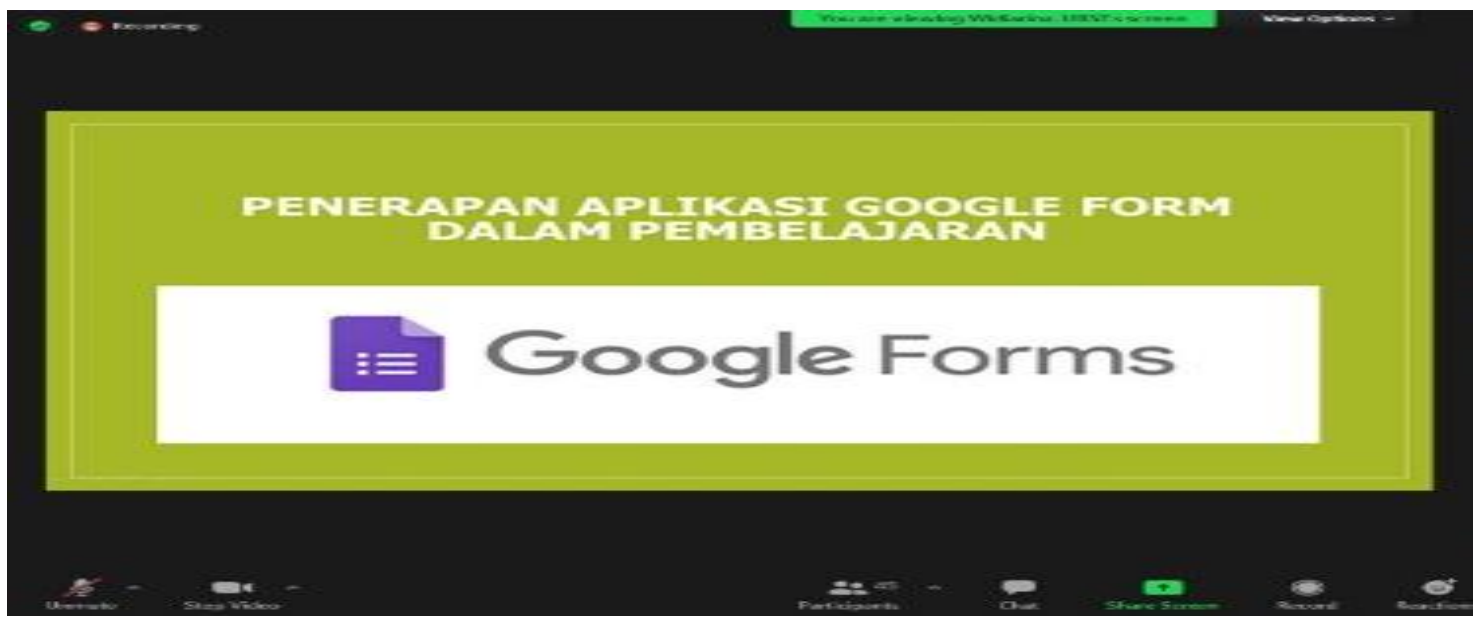

Gambar 1. Sesi Pemaparan Materi

Dengan dilaksanakannya pengabdian masyarakat di Yayasan Madrasah Al Muhajirin, peserta menjadi bertambah wawasan dan pengetahuannya dalam memahami pembuatan aplikasi google form sehingga dapat menjaga komunikasi dengan baik. Pihak Yayasan Madrasah Muhajirin, Bekasi sangat kooperatif dalam pelaksanaan pengabdian masyarakat dan menyambut dengan antusias kegiatan ini, selain tertarik dan menarik dalam kegiatan ini, peserta berharap dalam melakukannya Kembali di lain kesempatan dengan tema yang berbeda, sehingga peran pembelajaran baik online maupun offline nantinya akan sangat membantu dalam proses di kelas, mengingat teknologi computer dan internet menrupakan salah satu upaya penunjang yang diharapkan dapat berperan dan terbiasa dalam menggunakan disegala bidang dan peserta didik akan mudah menggunakannya dalam menyelesaikan berbagai persoalan-persoalan yang terjadi seperti pekerjaan rumah dan tugastugas sekolah. 


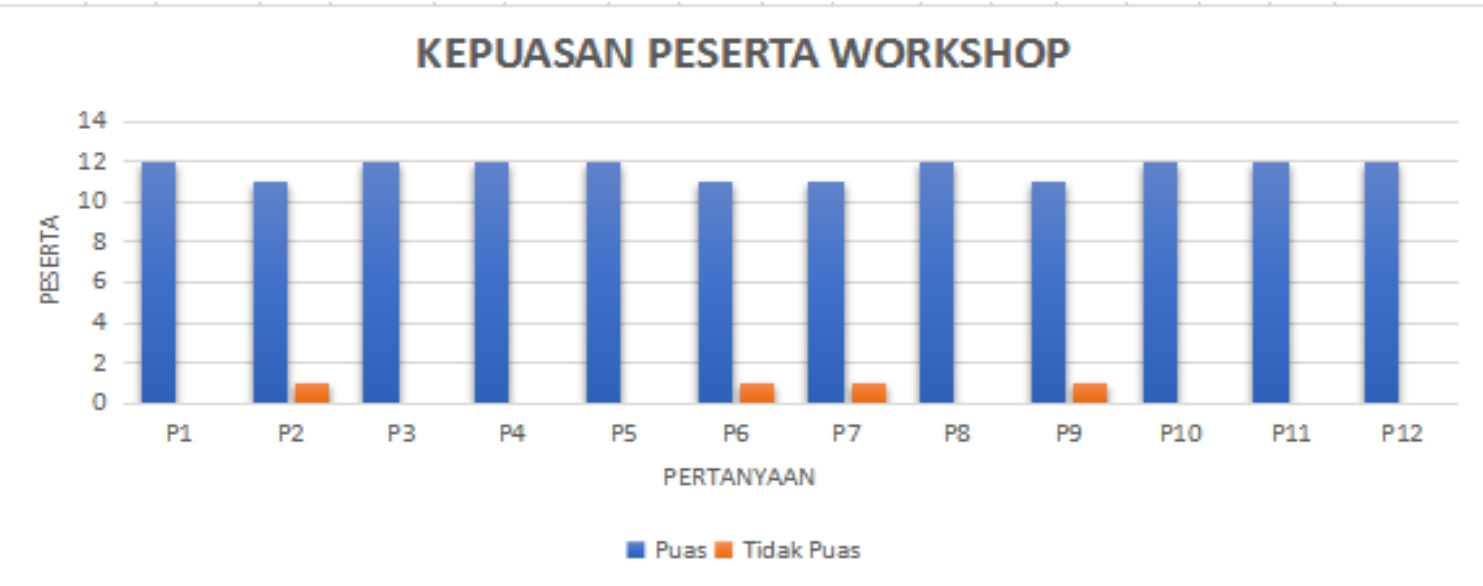

Gambar 2. Grafik Hasil Kuesioner Pengabdian Masyarakat

Berdasarkan hasil kegiatan pengabdian kepada tenaga pengajar Yayasan Madrasah Muhajirin, Bekasi dapat disimpulkan bahwa kegiatan workshop berjalan dengan baik dan lancar dengan dibuktikan dari hasil kuesioner yang diberikan pada akhir kegiatan dan peserta rata-rata merasakan puas terhadap penyampaian penyuluhan sesuai dengan kebutuhan peserta. Selain itu kontribusi mitra terhadap pelaksanaan pengabdian masyarakat adalah membantu menyediakan tempat, sarana serta prasarana kegiatan pengabdian masyarakat Yayasan Muhajirin, Bekasi, memberikan konsumsi dan kuota paket internet kepada peserta pelatihan.

\section{Simpulan dan Tindak lanjut}

Melalui kegiatan pengabdian kepada masyarakat dapat disimpulkan bahwa secara keseluruhan kegiatan pengabdian berjalan dengan baik. Aplikasi teknologi daring, seperti Zoom, Meet, Elearning dapat di optimalkan penggunaannya sebagai media pembelajaran dan pendidikan jarak jauh secara digital dengan fitur tambahan. Kegiatan pengabdian yang telah dilaksanakan diharapkan dapat memberikan pengetahuan dan informasi mengenai pembelajaran dan pendidikan melalui Zoom, Meet, Elearning serta memotivasi para peserta didik untuk mengoptimalkan penggunaan teknologi daring sebagai media sosial.

Selain itu, kegiatan pengabdian diharapkan mampu meningkatkan keterampilan peserta didik dalam menuangkan gagasan, ide diskusi, pertanyaan dan pemecahan masalah pembelajaran dalam bentuk tulisan yang dikombinasikan dengan foto maupun video dalam memberikan pengetahuan dan informasi mengenai pembelajaran dan pendidikan. Dari kegiatan pengabdian yang telah dilaksanakan, peserta berharap agar kegiatan yang sejenis dapat dilakukan secara bekelanjutan seperti misalnya sosialisasi tentang foto hasil tugas peserta didik dan pekerjaan rumahnya.

\section{Daftar Pustaka}

Enny, M. (2019). Manajemen Sumber Daya Manusia (M. Erma W, Ed.; 1st ed.). Ubhara Manajemen Press.

Kurniawan, A., Prambudi Utomo, K., \& Rukiastiandari, S. (n.d.). Influence of Culture and Organizational Commitment to Performance Management of The Covid-19 Pandemic in The Bekasi City Manpower ofice. International Journal Of Science. http://ijstm.inarah.co.id 
Lestiowati, R., Fadly, R., Krisna Wardhana, A., \& Utomo, K. P. (2021). Pengaruh Budaya dan Kualitas terhadap KepuasanKerja di Masa Pandemi Covid-19 Badan Kepegawaian Negara Jakarta. Jurnal Kajian Ilmiah, 21(3), 353-364. http: / / ejurnal.ubharajaya.ac.id/index.php/JKI

Sourial, N., Longo, C., Vedel, I., \& Schuster, T. (2018). Daring to draw causal claims from non-randomized studies of primary care interventions. Family Practice, 35(5), 639-643. https://doi.org/10.1093/fampra/cmy005

Suhendri, S., Sabri, R., Arifin, Z., Rahman, M. A., Ainaya, T., \& Fahmi, H. A. (2021). Pelatihan Pembelajaran Jarak Jauh (PJJ) Pada Masa Pandemi Covid-19 Bagi Guru Sekolah Dasar Islam Terpadu (SDIT) DOD Medan. Jurnal Pengabdian Kepada Masyarakat, 27(1), 1-5.

Sumarsid, S., \& Winarso, W. (2020). PENGANTAR BISNIS (1st ed., Vol. 1). CV AA. Rizky.

Syarief, F., Prambudi Utomo, K., Supriyanto, S., \& Kamal, F. (2019). Cultural Effects, Work Propriety and Values in Perspective Trust Level in The Ministry of Education and Culture. INSIGHT JOURNAL, 6, 2-14.

Utomo, K. P., \& Kamal, F. (2020). A Strategy to Improve the Learning of Political Culture with Debate Method in Vocational High School 1 Bekasi. International Journal on Research in STEM Education, 2(1), 1-12. https://doi.org/10.31098/ijrse.v2i1.217

Syarief, F., Utomo, K. P., Rukiastiandari, S., Widiarina, W., \& Yunita, Y. (2021). PERAN TEKNOLOGI DARING DALAM PEMBELAJARAN DI MASA PANDEMI PADA WARGA RT. 010 TEGAL PARANG. Jurnal Pengabdian Masyarakat: Pemberdayaan, Inovasi dan Perubahan, 1(2).

Yusuf, F., Shinta, M. R., \& Fransisco, S. (2020). Effect of Work Motivation and Compensation on Employee Performance at PT.Askrindo (Persero) Cikini Central Jakarta. Journal of Research in Business, Economics, and Education, 2(6 Desember), 1382-1387. http://e-journal.stiekusumanegara.ac.id 